\title{
DE-EXTINCTION AND REPRESENTATION: PERSPECTIVES FROM ART HISTORY, MUSEOLOGY, AND THE ANTHROPOCENE
}

ROSIE IBBOTSON

\section{Abstract}

This article considers issues in genetic rescue using art-historical and museological perspectives, arguing that advances made in these fields constitute vital critical context for understanding the implications and assumptions of de-extinction and its methods. It focuses on the role of visual representation within these discourses, and on resonances between museology, strands within ecocriticism, and notions of the Anthropocene.

Using the case study of the extinct huia (Heteralocha acutirostris), this article addresses distortions inherent in the technologies for representing and seeing upon which impressions of extinct species so often rest, and raises questions about how de-extinction initiatives engage with their visual sources. Furthermore, it highlights the problematics of anthropocentric visual regimes having the potential to mediate animals recreated through de-extinction, and raises questions about what the implications of this might be for their intra- and interspecies relationships. This article also considers the museum, an institution in which contested practices such as collecting, curating, conserving, and canon formation echo debates and processes within ecology management, including those surrounding de-extinction. The museum thus emerges as an analogy for-and an engine of-genetic rescue and the Anthropocene.

Keywords: de-extinction, representation, huia, visual record, image, remediation, art history, museology, extinction, Anthropocene

This article seeks to bring art-historical and museological perspectives to bear on discourses surrounding the highly controversial idea of de-extinction. Many discussions arguing for why extinct species should be recovered, and how this might be done, implicitly or explicitly revolve around questions of how such species 'look'. However, despite the centrality of appearance in these debates, it is frequently treated in an uncritical way - as stable, quantifiable, and knowable. This situation is further vexed by the frequent incompleteness of visual and material records pertaining to extinct species (and this is to say nothing of records of other aspects of them: for example, how they sounded, how they moved, and what their scents were- 
characteristics that play crucial roles in both intra- and interspecies interactions). ${ }^{1}$ A case in point is the huia (Heteralocha acutirostris), the principal example I refer to in this article. ${ }^{2}$ The huia was a relatively sizeable wattlebird endemic to Aotearoa New Zealand, which was last confirmed sighted in 1907 and was presumed extinct soon after (though occasional unconfirmed sightings occurred as late as the 1930sa fact that in itself raises questions regarding the role of 'legitimacy' in what gets to be considered as credible scientific evidence). ${ }^{3}$ The huia has been proposed as a candidate species for de-extinction, and in terms of its cultural significance-especially to the Ngāti Huia people, ${ }^{4}$ its reported behavioural traits, and its biological specificities, the bird is well-placed as both a charismatic and, scientists tell us, relatively practicable option. 5 The other strand to my discussion seeks to examine alignments between debates in ecocriticism and museological theory. With the politics of preservation being central to both, I hope to outline how museological ideas might productively complicate, lend insight into, and critique certain issues relating to de-extinction. ${ }^{6}$ For proponents of de-extinction and its detractors alike, robust debate around all its facets and entanglements is essential, especially given the high stakes.

The urgent need to bring holistic critical attention to bear on de-extinctionincluding diverse perspectives from the arts and (post)humanities—stems from the fact that it is no longer in the realm of science fiction, but has already started. Attempts to back-breed a plains zebra species towards the likeness of the extinct quagga sub-species have been under way in South Africa since 1987, 7 and in 2003, the Pyrenean ibex became extinct for the second time, after a live kid produced using cloning techniques survived several presumably very difficult minutes before dying on account of breathing difficulties. These are just two of a substantial number of

1 For a summary of some recent research into the smells of New Zealand birds, for example, see James Briskie, 'Odorous New Zealand birds', Marsden Fund Update 51 (January 2016): 1-2.

2 It should be noted that this article is not seeking to comment upon the advisability or otherwise of 'de-extincting' the huia; rather, the huia offers a rich and complex case study which demonstrates various issues that I am arguing are important to debates around de-extinction.

3 For discussions of how notions such as legitimacy and credibility get to police the boundaries of scientific discourse, see Thomas F. Gieryn, Cultural boundaries of science: Credibility on the line (Chicago, IL, and London: University of Chicago Press, 1999). For an examination of the contested nature of a (previously) declared extinction-the case of the South Island kōkako-see Kate Evans, 'In search of the Grey Ghost', New Zealand Geographic 140 (July-August 2016): 38-53.

4 Some consider Ngāti Huia to be an iwi (tribe); others consider it a hapū (subtribe) of the larger iwi Ngāti Raukawa.

5 The bird's relatively recent date of presumed extinction contributes to this. For a detailed summary of the huia's credentials — both in technological and cultural terms — as a candidate species for de-extinction, see Douglas Campbell, 'A case for resurrecting lost species—review essay of Beth Shapiro's, "How to clone a mammoth: The science of de-extinction"', Biology \& Philosophy (2016): 751-4, doi.org/10.1007/s10539-016-9534-2.

6 This might in turn shed further light on certain notions and commonplaces within the fields of art history and museology.

7 For a description of the Quagga Project, see Lucia Martinelli, Markku Oksanen, and Helena Siipi, 'De-extinction: A novel and remarkable case of bio-objectification', Croatian Medical Journal 55, no. 4 (August 2014): 424, doi.org/10.3325/cmj.2014.55.423. 
recent or ongoing projects relating to de-extinction, and a range of different species is being looked at. ${ }^{8}$ Visual sources, and impressions of how the species in question looked, occupy key roles in these projects, and in evaluations of their success.

\section{The Anthropocene and genetic imaginaries}

My article considers de-extinction as an archetypal phenomenon of the Anthropocene, a term used here in an expansive way. It was coined in relation to geology, ${ }^{9}$ but subsequently its meaning has diversified in various directions from the initial stratigraphical sense. Timothy Clark provides a useful overview of the various ways in which the term 'Anthropocene' is used, noting how it 'evades normal categories of attention'. ${ }^{10}$ As he describes it:

The term has rapidly become adopted in the humanities in a sense beyond the strictly geological. Its force is mainly as a loose, shorthand term for all the new contexts and demands—cultural, ethical, aesthetic, philosophical and political—of environmental issues that are truly planetary in scale. ${ }^{11}$

Nearly all of the candidate species for de-extinction disappeared - or rather, were disappeared, in large part by humans - during the course of the currently ongoing and anthropogenically propelled 'sixth mass extinction'. ${ }^{12}$ While these extinctions have at times occurred somewhat unnoticed and in many cases only indirectly as a result of human activity, other instances have been more deliberate, and it must be noted that even when people have been aware of extinctions approaching, understandings of this process, and of ecological change more generally, are historically specific. ${ }^{13}$ The huia is a stark case in point: driven to extinction in the decades around the fin de siècle-encouraged in part by the ideas and endeavours

8 Rich and critically nuanced discussions of such initiatives can be found in Amy Fletcher's book Mendel's ark: Biotechnology and the future of extinction (New York, NY: Springer, 2014).

9 See Paul J. Crutzen, 'Geology of mankind', Nature 415 (3 January 2002): 23, doi.org/10.1038/415023a. Unlike for all the other geological epochs, the transition to the Anthropocene-which still remains to be officially accepted-is being monitored consciously from within, something that carries a certain irony given humans' responsibility for it. That said, it should be noted that the precise period in which the Anthropocene began is also contested. In addition, the term itself is increasingly controversial within (post)humanities discourses (and beyond), where various other names_-for example, Capitalocene, Chthulucene, and Plantationocene- are being explored as well. See, for example, Donna Haraway, 'Anthropocene, Capitalocene, Plantationocene, Chthulucene: Making kin', Environmental Humanities 6 (2015): 159-65, doi.org/10.1215/22011919-3615934.

10 Timothy Clark, Ecocriticism on the edge: The Anthropocene as a threshold concept (London: Bloomsbury Academic, 2015), x.

11 Clark, Ecocriticism on the edge, 2.

12 This alignment is in part because the resurrection of species that became extinct more recently poses fewer biotechnological challenges.

13 See, for example, Fletcher, Mendel's ark, 2-3; Markku Oksanen and Helena Siipi, 'Introduction: Towards a philosophy of resurrection science', in The ethics of animal re-creation and modification: Reviving, rewilding, restoring, ed. Markku Oksanen and Helena Siipi (Basingstoke and New York, NY: Palgrave Macmillan, 2014), 1-3, doi.org/10.1057/9781137337641_1. 
of the amateur but ambitious ornithologist Walter Buller, who was aware of how endangered the species was ${ }^{14}$ —it highlights radical shifts in how extinction has been viewed since the concept eventually took root, in the mid-nineteenth century, in dominant discourses of natural history. ${ }^{15}$ While the huia and some other species were given legal protection in 1892, this was critically late and even then only patchily observed-including by Buller himself, who also promoted preservation efforts.

As this might suggest, Buller was a controversial and rather contradictory figure, who was variously esteemed and disliked by both his Māori and Pākehā (European settler) contemporaries. Ross Galbreath's biography of Buller highlights his tenacity and propensity for self-promotion, and his skilful but somewhat brazen ability to manoeuvre through the scrutiny his professional actions sometimes invited. ${ }^{16}$ Born in 1838 on a Wesleyan mission in what was to become New Zealand's Far North District, Buller was from the beginning immersed in the cultural landscapes that his later career was to exploit. His competency in the Māori language stemmed from this time, and expedited his early career, which included working with the Native Department, tenure as a resident magistrate in Manawatū, and various roles supporting the colonial administration-including in its coercive acquisition and division of Māori lands. While the categories of 'amateur' and 'professional' were much less clearly defined in the nineteenth century, Buller was not a scientist by training, and pursued his ornithological research in his spare time. Nonetheless, this was significantly aided by the support he received from influential political figures such as George Grey, William Fox, and Isaac Earl Featherston. Perhaps the most conspicuous form this took was assent for Buller to take leave from his magisterial position (which was initially kept open for him) to travel to Britain to complete his monumental ornithological atlas, A history of the birds of New Zealand. Sensing that the book would be of significant strategic importance, the New Zealand Government had also put up substantial funds for its production. To enable this secondment in London, a part-time role was contrived for Buller as private secretary to Featherston, who from 1871 was to be stationed there in the new office of Agent-General.

Though his leave was supposed to have been limited to 18 months, Buller extended it, and the publication of all five parts of the first edition of Birds was completed by early 1873 . The work met with significant acclaim, ${ }^{17}$ and through it Buller adroitly

14 Indeed, Buller fully anticipated that a significant number of the bird species that he documented would soon be extinct (see Walter Buller, 'Prospectus', reproduced in A history of the birds of New Zealand (London: John Van Voorst, 1873), iii), and tragically, a significant number of them did. In the data in Kerry-Jayne Wilson's book Flight of the huia, however, which looks at New Zealand's ecology more generally, the huia is the only species for which 'collectors' is listed among the key causes of its extinction. Kerry-Jayne Wilson, Flight of the huia: Ecology and conservation of New Zealand's frogs, reptiles, birds and mammals (Christchurch: Canterbury University Press, 2004), 134.

15 For a brief summary of the rise of the notion of extinction, see Oksanen and Siipi, 'Introduction: Towards a philosophy of resurrection science', $1-2$.

16 See Ross Galbreath, Walter Buller: The reluctant conservationist (Wellington: GP Books, 1989).

17 See, for example, Galbreath, Walter Buller, 108-9. 
brokered his acceptance into European scientific milieux, including the London elite whose approval he particularly prized. Indeed, while overseas Buller appears to have capitalised on every opportunity for advancing his career and reputation. In addition to numerous meetings with renowned 'men of science', he qualified as a barrister; as Galbreath observes, by the time Buller returned to Aotearoa, ' $\mathrm{h}] \mathrm{e}$ had all that he had come to London for'. ${ }^{18}$ Meanwhile, however, not all had felt that his sojourn was a success: back in New Zealand it had provoked the derision of opposition politicians, who denounced his generous treatment-including his salary, and the somewhat nominal nature of his role with Featherston-as patronage. ${ }^{19}$ Galbreath notes that 'Buller's leave was a continuing embarrassment for the Government', ${ }^{20}$ and during one heated exchange in parliament while he was still overseas, Buller was described - perhaps in an impish nod to the aviary he maintained—as 'one of those colonial pets ... to be kept in affluence during their natural lives. ${ }^{21}$

Among other things, Buller's varied career highlights the multifaceted and intersecting nature of the causes of environmental violence-something thrown into particularly sharp relief by the speed and scope of the ecological changes made in nineteenth-century Aotearoa. As an instrument of colonial policy, the law played a significant role in this climate of destruction, and the forcible redistribution of land constituted a particular assault on indigenous life there-people, plants, and birds. It was certainly catastrophic for the huia, which was drawn into the eye of a storm of coinciding circumstances, and whose extinction resulted from a constellation of interdependent factors. The seizure and deforestation of Māori lands in the service of rapidly expanding settler agriculture, for example, threatened the huia not only in terms of habitat loss, but also because it compromised the indigenous social structures on which long-established protections for natural resources-including the huia specifically—depended. ${ }^{22}$ Huia needed mature forests in order to thrive, as rotting tree trunks were important for providing them with food such as huhu beetle larvae (Prionoplus reticularis); ${ }^{23}$ once destroyed, this habitat could not be regenerated quickly. Furthermore, attempts to displace Māori authority over the land destabilised rāhui, the system of temporary restrictions which-along with other functions_-was a conservation method through which Māori had maintained

18 Galbreath, Walter Buller, 113.

19 Galbreath, Walter Buller, 99.

20 Galbreath, Walter Buller, 107.

21 Wi Parata, of the Ngāti Toa and Te Ātiawa peoples, and member of parliament for Western Māori, added: ' $[\mathrm{a}] \mathrm{s}$ far as the Maoris [are] concerned, that gentleman might stop in England altogether'. Quoted in Galbreath, Walter Buller, 99.

22 Cathy Marr, 'Wairarapa twentieth century environmental overview report: Lands, forests and coasts', Crown Forestry Rental Trust research report, Wairarapa ki Tararua inquiry, WAI863, A025 (August 2001): 40, 42.

23 Marr, 'Wairarapa twentieth century environmental overview report', 41; W. J. Phillipps, The book of the huia (Christchurch: Whitcombe and Tombs, 1963), 14, 25-7. 
strong and stable numbers of huia over a long period. ${ }^{24}$ In Cathy Marr's research report for the Waitangi Tribunal on Wairarapa lands, forests, and coasts, the huia is discussed as one example from the region of how the Crown often 'failed to ensure adequate protections for traditional systems of use and management, especially if these conflicted with the views or interests of the dominant settler community', 25 and Marr notes how the species was considered 'especially tapu, one of the most sacred of forest birds' ${ }^{26}$ In the decades leading up to the huia's extinction, a number of Māori rangatira (chiefs) sought government support for the species' protection, but many Pākehā (and some Māori) hunters were willing-or compelled by circumstances - to disregard the rather feeble and critically overdue sanctions that politicians put in place. ${ }^{27}$ Others continued to call for a more holistic strategyas Māori leaders challenged the government, '[y] ou have prohibited the killing of the Huia, under a heavy penalty, and yet you allow the forests, whence it gets its subsistence, to be destroyed! Where is the consistency of that?'28

The roaring international trade in feathers was a significant factor in why the hunting of huia and other birds did not initially abate, and the 1892 protective legislation proved ineffective in addressing this particular underlying cause. ${ }^{29}$ This lucrative industry was fuelled by Victorian and Edwardian metropolitan fashions, and in 1873 alone, for example, in excess of 600 huia skins were obtained. ${ }^{30}$ Among Māori, head adornments incorporating the huia's distinctive white-tipped tail feathers had for a long time been worn by individuals of high status, but the appropriation of this symbol by Europeans_-spiking after a widely reported visit to Aotearoa in 1901 by the Duke of Cornwall and York, who was presented with a huia tail feather to wear in his hat ${ }^{31}$ — caused demand to outstrip what could be sourced sustainably.

24 See Clark S. Monson, 'Cultural constraints and corrosive colonization: Western commerce in Aotearoa/New Zealand and the extinction of the huia (Heteralocha acutirostris)', Pacific Studies 28, no. 1/2 (March/June 2005): 68-93.

25 Marr, 'Wairarapa twentieth century environmental overview report', 40.

26 Marr, 'Wairarapa twentieth century environmental overview report', 40.

27 Marr, 'Wairarapa twentieth century environmental overview report', 41-3; Monson, 'Cultural constraints and corrosive colonization', 82 .

28 Interestingly, this is quoted in Buller's 1905 Supplement to the 'Birds of New Zealand', as part of a passage in which he appears to be attempting some pre-emptive damage control on the reputation he was leaving to posterity: 'I know it is the fashion to raise a wail over the disappearance of the New Zealand birds, and to invoke the powers in the way of protective measures. But there are certain species which, from the nature of the case, it is impossible to preserve, and it seems to me that the Huia is one of these ... For this reason, I think it is to be regretted that more specimens of a bird destined ere long to become extinct do not exist in our local museums. A few years hence it will be impossible to obtain any. Fortunately, long before the introduction of the prohibitory law, I had secured a dozen or more superb specimens for my own collection. Without exception, these were obtained in what was then known as the "Forty-mile Bush", a district now entirely covered with green fields and smiling farms'. Walter Buller, Supplement to the 'Birds of New Zealand' (London: The author, 1905), 2:157.

29 Marr, 'Wairarapa twentieth century environmental overview report', 43.

30 Kathryn M. Hunter, 'Colonial hunting cultures', in Eco-cultural networks and the British empire: New views on environmental history, ed. James Beattie, Edward Melillo, and Emily O'Gorman (London and New York, NY: Bloomsbury Academic, 2015), 189.

31 Phillipps, The book of the huia, 39; Monson, 'Cultural constraints and corrosive colonization', 83. 
While Kathryn M. Hunter notes more generally that ' $[t]$ he effects of plume hunting on bird populations are difficult to gauge, especially when other factors such as the wholesale destruction of habitat for agriculture or the introduction of predators and competitors are taken into account', ${ }^{32}$ huia only had 12 of these in-demand tail feathers, which presumably put their numbers at greater risk. Buller too played a role in the feather trade-for example, when he became aware of a London dealer seeking plumes 'for ladies' costumes' (specifically, kererū skins in lots of one thousand), he wrote to a contact in New Zealand who he thought might be willing to arrange their supply. ${ }^{33}$ As Galbreath observes, 'Buller saw no irony in encouraging the largescale destruction of the birds on which his own success was based'. ${ }^{34}$ Buller was also involved in the acclimatisation societies that introduced to Aotearoa predators and competitors for its flora and fauna, in an effort to make the environment more 'agreeable' to European settlers-another aspect of the sweeping and multifaceted processes by which, as Geoff Park put it, 'the wild of the new land is punished for its unfamiliarity'. ${ }^{35}$ While Buller's contribution to the demise of the huia is best known in terms of his specimen collecting (for museums, for scientific investigation, and for himself, which encouraged other private collectors), in one way or another he seems to have been involved in all of the threats that the bird faced.

The anthropogenic nature of this sort of environmental violence, which targeted birds as well as their habitats, ironically drives the arguably anthropocentric calls for the implementation of de-extinction technologies. ${ }^{36} \mathrm{~A}$ kind of doubling, and intensifying, is suggested. Moreover, as Marcus Hall observes of rewilding more generally, it is a 'potentially enigmatic practice ... whereby human action is meant to remove the results of human action. ${ }^{37}$ Indeed, some proponents of de-extinction have attempted to frame this science not as a compounding of anthropogenic effects, but more as a reversal —or at least partial ameliorationof them. Furthermore, there have been attempts to justify de-extinction agendas in terms of 'moral' imperatives, as a sort of 'atonement' for humans'-or more accurately, some humans'-ecological sins. In the face of what Gerardo Ceballos,

\footnotetext{
32 Hunter, 'Colonial hunting cultures', 194.

33 Galbreath, Walter Buller, 110.

34 Galbreath, Walter Buller, 110.

35 Geoff Park, Theatre country: Essays on landscape \& whenua (Wellington: Victoria University Press, 2006), 9.

36 However, it should also be noted that it would be problematic to assume complete continuity between the people who endangered a species, and those who would like it to be brought back, and it is vital to remember that not all groups of humans have played equal parts in environmental destruction.

37 Marcus Hall, 'Introduction: Tempo and mode in restoration', in Restoration and history: The search for a usable environmental past, ed. Marcus Hall (New York, NY, and London: Routledge, 2010), 7, doi. org/10.4324/9780203860373. Furthermore, Fletcher uses the policy sciences notion of the 'wicked problem' to characterise 'the biodiversity crisis—and the associated problem of extinction' (5). See, for example, Fletcher, Mendel's ark, 5-7.
} 
Anne H. Ehrlich, and Paul R. Ehrlich term an 'ongoing biotic genocide', ${ }^{88}$ Tracey Heatherington wryly notes how 'the moral terrain of extinction is tremendously evocative for the genetic imagination. ${ }^{39}$ However, Beth Shapiro-an expert in ancient DNA research and a cautious supporter of technologies considered part of the broad fold of 'the science of de-extinction'-observes that, 'Bringing these species back goes some way to mitigate the guilty conscience ... But mitigation of guilt is not a compelling reason to bring something back to life. ${ }^{40}$ Indeed, critiques of de-extinction caution that, among other things, it could cause further neglect of the conservation of existing species, and philosophical questions have been raised as to the ontological status and authenticity of what exactly would be being put back. ${ }^{41}$ Furthermore, given the glaring issues for animal rights likely to be involved in many practices of de-extinction, in most instances it seems hard to make the case that bringing back a species would be for reasons beyond the anthropocentric. While this is not to suggest that anthropocentric reasons are automatically invalid, it is important to note in this context that what is thought to be 'good' for a given species as a whole does not necessarily scale to what is 'good' for an individual within that species. While de-extinction projects are sometimes rationalised using the idea that revived keystone species might prop up whole ecosystems, ${ }^{42}$ certainly at the moment this seems rather optimistic, given the challenges involved in making these species robust enough even to survive themselves. ${ }^{43}$ Indeed, even the notion of a discrete, clearly defined species is misleadingly monolithic, as many creatures require other organisms — such as those present in a gut microbiome-in order to function effectively. As Benjamin Bratton puts it, ' $r$ ] eal biology doesn't conform to clean divisions between organisms and species and landscapes ... Everywhere, we are situated within economies of nested parasitism'. ${ }^{44}$

\footnotetext{
38 Gerardo Ceballos, Anne H. Ehrlich, and Paul R. Ehrlich, The annihilation of nature: Human extinction of birds and mammals (Baltimore, MD: Johns Hopkins University Press, 2015), x. It should be noted that Paul and Anne Ehrlich have spoken out strongly against de-extinction.

39 Tracey Heatherington, 'From ecocide to genetic rescue: Can technoscience save the wild?', in The anthropology of extinction: Essays on culture and species death, ed. Genese Marie Sodikoff (Bloomington, IN: Indiana University Press, 2012), 49.

40 Beth Shapiro, How to clone a mammoth: The science of de-extinction (Princeton, NJ, and Oxford: Princeton University Press, 2015), 26.

41 See, for example, Douglas Campbell's recent research; Fletcher, Mendel's ark; Martinelli, Oksanen, and Siipi, 'De-extinction', 423-7.

42 See, for example, Shapiro, How to clone a mammoth, 10.

43 Indeed, the myriad health problems faced by some breeds of animal produced by intensive selective breeding do not bode well for certain methods and techniques of de-extinction.

44 Bratton continues, 'As for humans, we estimate more than 10,000 microbial species occupy the human ecosystem, and that inside your body well over $90 \%$ of the genes are non-human. You too are a "them", an identity which may also challenge the neat coherency of "the human" as a geological actor'. Benjamin H. Bratton, 'Notes on extinction, emergence, and biochemical design', www.bratton.info/projects/texts/notes-on-extinction-emergenceand-biochemical-design, accessed 25 October 2015.
} 


\section{Curating the Anthropocene?}

The rather treacherous illusion that de-extinction would somehow 'turn back the clock' might usefully be substantiated using museological discourses, which have problematised understandings of such ideas as collection, conservation, and curation. De-extinction has parallels with all of these aspects of museum practice, since it necessarily involves the incomplete selection of which species to reintroduce and maintain, where and how to do this, and huge amounts of money to enable and maintain it all. ${ }^{45} \mathrm{~A}$ post-de-extinction landscape might therefore be envisaged as a sort of living museum, not unlike a zoo. Timothy Morton has suggested a related idea for the whole notion of 'Nature' itself, which he critiques. In relation to so-called 'wilderness' reserves, he has observed how 'Nature was a special kind of private property, without an owner, exhibited in a specially constructed art gallery. The gallery was Nature itself, revealed through visual technology in the eighteenth century as "picturesque"-looking like a picture'. ${ }^{46}$ Morton even goes so far as to assert that 'landscape' is 'a word for a painting, not actual trees and water', ${ }^{47}$ further alluding to the complex, long-standing, and two-way mediations between art and the environment.

However, if the Anthropocenic post-de-extinction environment might be a museum, then at the moment it seems to be one with little coordinated curatorial oversight. The rather substantial list of candidate species mooted for de-extinction does not for the most part appear to derive primarily from an envisioned attempt to restore a particular ecosystem and all its complex biotic interactions. Rather, it is a somewhat incoherent selection which, as Heatherington (among others) notes, almost entirely comprises 'charismatic megafauna'. ${ }^{48}$ Many of these candidate species appear to have a champion who is personally and professionally invested in bringing it back. ${ }^{49}$ As this reinforces, just as for the acquisition, preservation, and display of objects in a museum, de-extinction is inevitably informed not just by practical and logistical constraints, but also by culture, politics, and ideological agendas, and the so-called 're-wilded' landscape must be seen as highly constructed. ${ }^{50}$

45 The same could also be said of existing, less radical practices of environmental conservation, since these also involve selectiveness, interpretative decision-making, and cost. However, just as critiques of museums hardly ever seek to be arguments against these institutions' existence, to critique approaches within ecological conservation initiatives is certainly not automatically to suggest that they should not happen.

46 Timothy Morton, The ecological thought (Cambridge, MA, and London: Harvard University Press, 2010), 5-6. 47 Morton, The ecological thought, 10. Other thinkers, such as Geoff Park, have emphasised the plurality in meaning of the term 'landscape'-see, for example, Park, Theatre country, 9-10.

48 Heatherington, 'From ecocide to genetic rescue', 44.

49 However, this is not to seek to invalidate such motivations, and indeed these are of course not the only sorts of reasons why people might seek for extinct species to be revived.

50 Jamie Lorimer's use of the notion of 'ontological choreography' (after Donna Haraway, after Charis Thompson) is relevant here. See Jamie Lorimer, Wildlife in the Anthropocene: Conservation after nature (Minneapolis, MN, and London: University of Minnesota Press, 2015), 12. 
Furthermore, a much-discussed question within both the material heritage sector and within environmental histories is to what point in the past should this 'clock' be wound back? The determination, and indeed even the notion, of desired 'baseline' states is again hotly contested and necessarily ideological, ${ }^{51}$ and as various debates within ecocriticism discuss, there is no 'neutral' ground in the Anthropocene..$^{52}$ Morton describes humans' dizzying realisation of their inexorably destructive entanglements as 'a new ecological aesthetics: dark ecology ... The form of dark ecology is that of noir film. The noir narrator begins investigating a supposedly external situation, from a supposedly neutral point of view, only to discover that she or he is implicated in it'. ${ }^{3}$ The use of the cinematic analogy implies the possibilities of the arts for grappling with how we might attempt to represent and comprehend the Anthropocene, and its characteristic phenomena such as de-extinction.

The preponderance of charismatic megafauna among the candidate species for de-extinction also invites art-historical and museological critiques of the distorting effect of canons within art and material culture. 'Charismatic' species might be thought of as 'exciting' creatures that in life or posthumously have accrued some kind of cultural capital, and as such their relation to less-celebrated species parallels the position of canonical artworks in relation to that of everyday objects. It should be noted that charismatic species are not necessarily 'keystone' species-that is, those whose roles are disproportionately influential within ecological networksjust as canonical works of art are not necessarily the most illuminating. However, charismatic species and canonical artworks share the ability to capture public imagination, and by extension generate significant amounts of interest, and with this, resources. Because of their mutual rarity, it is overwhelmingly through images and other visual media that they do this. ${ }^{54}$ Technolibertarian inclinations are evident within some de-extinction discourses, and Bratton observes how "De-extinction" is a hot investment vehicle for Silicon Valley riches looking for high-risk/high-

51 For a range of perspectives on the notion of baselines in environmental restoration, see Marcus Hall, ed., Restoration and history: The search for a usable environmental past (New York, NY, and London: Routledge, 2010). And as Slavoj Žižek comments, 'One cannot even say that all we need do is restore the situation to its natural balance. To what balance?’ Slavoj Žižek, Living in the end times (London and New York, NY: Verso, 2011), 350.

52 Furthermore, anthropogenic effects have been changing environments for centuries.

53 Morton, The ecological thought, 16-17.

54 Lorimer makes a similar point with respect to wildlife, noting that 'Western publics are much more likely to encounter the charismatic organisms about which they are so concerned in print, online, or on TV than they are to meet them in the flesh'. Lorimer, Wildlife in the Anthropocene, 119. 
reward intellectual property. ${ }^{55}$ Museums are already very familiar with the frequently compromising and distorting effects of investment, such as in the form of philanthropy, and museological theorists ${ }^{56}$ have interrogated this at length. ${ }^{57}$

The case study of the huia particularly animates the parallels between de-extinction and museological issues, because practices of collection and circulation, and certain contemporary Eurocentric beliefs about what constituted 'preservation', played a decisive role in the species' annihilation. Its story demonstrates causalities between visual representation, museums, and extinction, as Buller collected and documented the bird whilst simultaneously_ and knowingly_-sealing its fate. ${ }^{58} \mathrm{His}$ sizeable and lavish Birds of New Zealand (from which perhaps the most widely-circulated images of the huia are taken) ran to a second edition in 1888, and a supplement in 1905, and was a competitive nod to John Gould's volumes on Europe, Australia, and Great Britain, and John James Audubon's on America. Birds of New Zealand is politically charged and elegiac, and reveals Buller's belief-widely shared among Europeans in nineteenth-century New Zealand-that the extinction of native birds was inevitable now that they faced competition from supposedly 'superior' introduced European species. ${ }^{59}$

Until it was effectively too late, Buller apparently understood 'conservation' only in museological and documentary terms, and not in the ecological sense understood today. Privileging specimens over living huia, or 'representation' over reality, he appears to have acted under the influence of an imperialistic fervour that soughtproblematically and ironically - to vindicate and even reify Charles Darwin's theory of evolution by natural selection. In the 'Prospectus' for the initial edition of his Birds book, Buller wrote, '[i]t has been the author's desire to collect and place on record a complete life-history of these birds before their final extirpation shall have rendered such a task impossible', ${ }^{60}$ and his hastening of the demise of the huia (and other birds) was framed as a way of immortalising the last of the species

\footnotetext{
55 Bratton, 'Notes on extinction, emergence, and biochemical design'.

56 See, for example, Shearer West, 'The devaluation of "cultural capital": Post-modern democracy and the art blockbuster', in Art in museums, ed. Susan M. Pearce (London: Athlone, 1995), 80-4.

57 Indeed, in the Thylacine Cloning Project (1999-2005) at the Australian Museum in Sydney, issues of deextinction, and museums' need to secure funding, were to collide. As Fletcher has discussed, this initiative 'reflected a new, neoliberal era of diminished Government support for public museums and a concomitant need to attract new (primarily corporate) funders' (74). Fletcher incisively analyses the optics of this project, describing its 'ongoing struggle between science and spectacle' (78), and notes the status of the thylacine as an icon, both in terms of the story of its drastic anthropogenic annihilation, and as the media-friendly bottled specimen referred to as the 'pickled pup', which—despite yielding scant usable DNA—served as a 'populariser' for both the technology and the museum (80). See Fletcher, Mendel's ark, 73-83.

58 The last confirmed huia sighting was, poignantly, just a year after Buller's death in 1906.

59 These sinister beliefs echoed the abhorrent and racist discourses of 'dying race' theory, which were also prevalent in New Zealand and elsewhere in the nineteenth century.

60 Buller continued that it was his aim 'to produce a book at once acceptable to scientific men in general and useful to his fellow colonists'. This vividly illustrates how understandings of science and empire were enmeshed, and demonstrates his ambitions in these areas. Buller, A history of the birds of New Zealand (1873), iii.
} 
within museum collections. ${ }^{61}$ Offering a tracer of the role played by museums in the 'imperial Anthropocene', huia skins and taxidermied specimens achieved wide global circulation as a sort of currency of the fledgling colonial museum, as remains of bird species native to Aotearoa were exchanged for historical material culture, usually from European collections. Perhaps the most famous example within this process is moa bones, the swapping of which did much to build the new museum collections of nineteenth-century New Zealand in the direction of Eurocentric canons of history. ${ }^{62}$

The dramatic illustration offered by the case of the huia of the relationship between institutional collecting and anthropogenic ecological change suggests that the museum might at times be envisaged as an agent of the Anthropocene, alongside such as the factory. At the least, the museum is a sort of quintessentially Anthropocenic product, broadly conceived, wherein humans (or some of them) seek to demonstrate systematic understanding and hegemony over the world around them. Furthermore, the huia vividly illustrates a motif that frequently appears within discourses associated with the 'new museology', which contends that museums might usefully be understood and critiqued as mausoleums of sorts, because things 'die' when they are put into museum collections-art, material culture, even ideas. To extend this parallel further, the museum, like de-extinction, paradoxically also gives its objects new—perhaps artificial—life, and both fields arguably seek to effect illusions of timelessness. Indeed museums are, ironically, also key storehouses of the DNA samples upon which so many de-extinction projects-and other forms of molecular biology research-depend, ${ }^{63}$ and taxidermied huia and skins would almost certainly play a vital role if the bird were to be technologically recreated.

\section{Representation and loss}

The case of the huia also highlights the need for de-extinction debates to take into account the potential elisions, framings, and distortions of representation. As Shapiro's discussions suggest, even in de-extinction techniques based on DNA

61 Looking ahead to the huia's future, Buller in 1870 commented that '[e]relong it will exist only in our museums and other collections'. Quoted in Phillipps, The book of the huia, 15.

62 It might be worth noting here that the massive moa bird has also been slated as a candidate species for deextinction. However, as Shapiro has explained, the moa's lack of living close relatives, and the age of the species' DNA, present an exceedingly complex — and thus currently unlikely - case in terms of recovery. See Shapiro, How to clone a mammoth, 31 .

63 See, for example, David M. Lambert, Lara D. Shepherd, Leon Huynen, Gabrielle Beans-Picon, Gimme H. Walter, and Craig D. Millar, 'The molecular ecology of the extinct New Zealand huia', PLoS ONE 4, no. 11 (November 2009): 1-10, doi.org/10.1371/journal.pone.0008019. 
and cloning, ${ }^{64}$ it is not quite as simple as same DNA will produce the same appearance, as this commonly-imagined formula does not take epigenetics into account. ${ }^{65}$ Even after highlighting this major complication, however, Shapiro's references to the way species look(ed) are not followed by critical discussion of the slippages, conventions, and constraints of image-making. ${ }^{66}$ Indeed, the images of the huia widely supposed to be the most 'scientific'-the ones from Buller's Birds-went through an elaborate series of remediations to get from the bird to the images in the books. A useful primer for this cascade of processes might be borrowed from Lorraine Daston and Peter Galison's summary of some key exigencies of scientific representation: 'images substitute for things, but they are already admixed with knowledge about those things. In order for nature to be knowable, it must first be refined, partially converted into (but not contaminated by) knowledge ... [images] represent the knower ... but also a certain collective way of knowing' ${ }^{67}$ The inevitable biases and omissions that this passage suggests are variously apparent in the means by which the illustrations for Buller's books were realised. To start with, J. G. Keulemans, the highly regarded ornithological artist selected by Buller to draw the huia and the other birds in the Birds of New Zealand volumes, was based in Britain and never actually set foot in Aotearoa. Furthermore, it is likely that, for most of the birds he drew, he did not get to encounter them live. While there were from time to time lone huia kept at the Zoological Gardens in London, seeing a single huia would have given only a partial picture: one of the things that many found so fascinating about this bird was their frequently pronounced sexual dimorphism - while the beaks of mature males were sturdy and angular, the mature females had longer, thinner, curving ones. ${ }^{68}$ These were sufficiently distinct for male and female huia to have for a time been believed members of different species, so especially in the light of the close attention Darwin had paid to beaks in his study of Galápagos finches, ${ }^{69}$ the huia challenged paradigms.

64 It is worth noting here that bird species, apparently, cannot be cloned, and instead require a technique called 'primordial germ cell transplantation' (PGCT). See Shapiro, How to clone a mammoth, 191; 153-8. This does not change my fundamental arguments, however, as these are not specifically focused on techniques involving cloning, or indeed on the huia alone.

65 For example, in response to a question about whether advances in ancient DNA research mean that a mammoth can now be cloned, Shapiro says: ' $[\mathrm{t}]$ he problem with this question is that it assumes that, because we can learn the DNA sequence of an extinct species, we can use that sequence to create an identical clone. Unfortunately, this is far from true. We will never create an identical clone of a mammoth' (11). Furthermore, Fletcher has examined the problematics of the 'metaphor of DNA as the code of life' (32). See Fletcher, Mendel's ark, for example 31-47; 51-4.

66 This, however, is fair enough, as Shapiro's extensive expertise is not—nor does she claim it to be - in the field of art history/visual culture.

67 Lorraine Daston and Peter Galison, Objectivity (New York, NY: Zone Books, 2010), 53.

68 See Lambert et al., 'The molecular ecology of the extinct New Zealand huia', 1-3.

69 See Charles Darwin, Narrative of the surveying voyages of His Majesty's ships Adventure and Beagle, vol. III: Journal and remarks (London: Henry Colburn, 1839). Interestingly, Darwin was among the various illustrious subscribers to the first volume of Birds of New Zealand, as was Gould. See Buller, A history of the birds of New Zealand (1873), v-vi. 
In the 1873 first edition of Buller's Birds, the plates are hand-coloured lithographs. Keulemans completed these drawings based on skins and taxidermy, some of which he prepared himself using different (but presumably similar) species as guides. This practice, symbolically at least, seems in conflict with the supposed imperative for accuracy in 'scientific' atlases. Further, Buller's advertising of the first edition as containing 'coloured illustrations, by Keulemans, of all the more interesting or characteristic forms' highlights a certain tension within the project-an arguably contradictory desire to fascinate as much as to inform. ${ }^{70}$ This mirrors one of the epistemological paradoxes at the heart of museological collecting and display, wherein the selective holdings purport to be both outstanding and representativeaims that are usually incompatible. Keulemans's taxidermy models were then used as the basis for watercolours, which were checked by Buller who had moved to London expressly to supervise the production of his book. ${ }^{71}$ Adding further layers to this cycle of potentially distorting remediation, ${ }^{72}$ the watercolours were then used as guides in the preparation of lithographic plates, which were then printed, and finally hand-coloured through outsourced labour. This was poorly remunerated, and often carried out in unsatisfactory working conditions where the light was bad. This was, of course, far from ideal given that these workers were trying to represent the subtlest tones-and characteristic bird-like iridescence—of creatures they had almost certainly never seen alive. Indeed, the representations of the huia in copies I have seen of this first edition of Birds do not capture much of the greenish sheen the birds are said to have had, and the modelling of these slightly varying images and their composition tend to lend them a certain flatness (Figure 1). In the picture, the female huia dominates, standing in front of the male with her curved beak framing his inward-turned head.

70 Buller, $A$ history of the birds of New Zealand (1873), iv.

71 This meant, however, that even Buller was away from most of the living examples, and thus was usually unable to compare the representations more directly.

72 For discussions of the notion of remediation, see Jay David Bolter and Richard Grusin, Remediation: Understanding new media (Cambridge, MA, and London: MIT Press, 1999). 


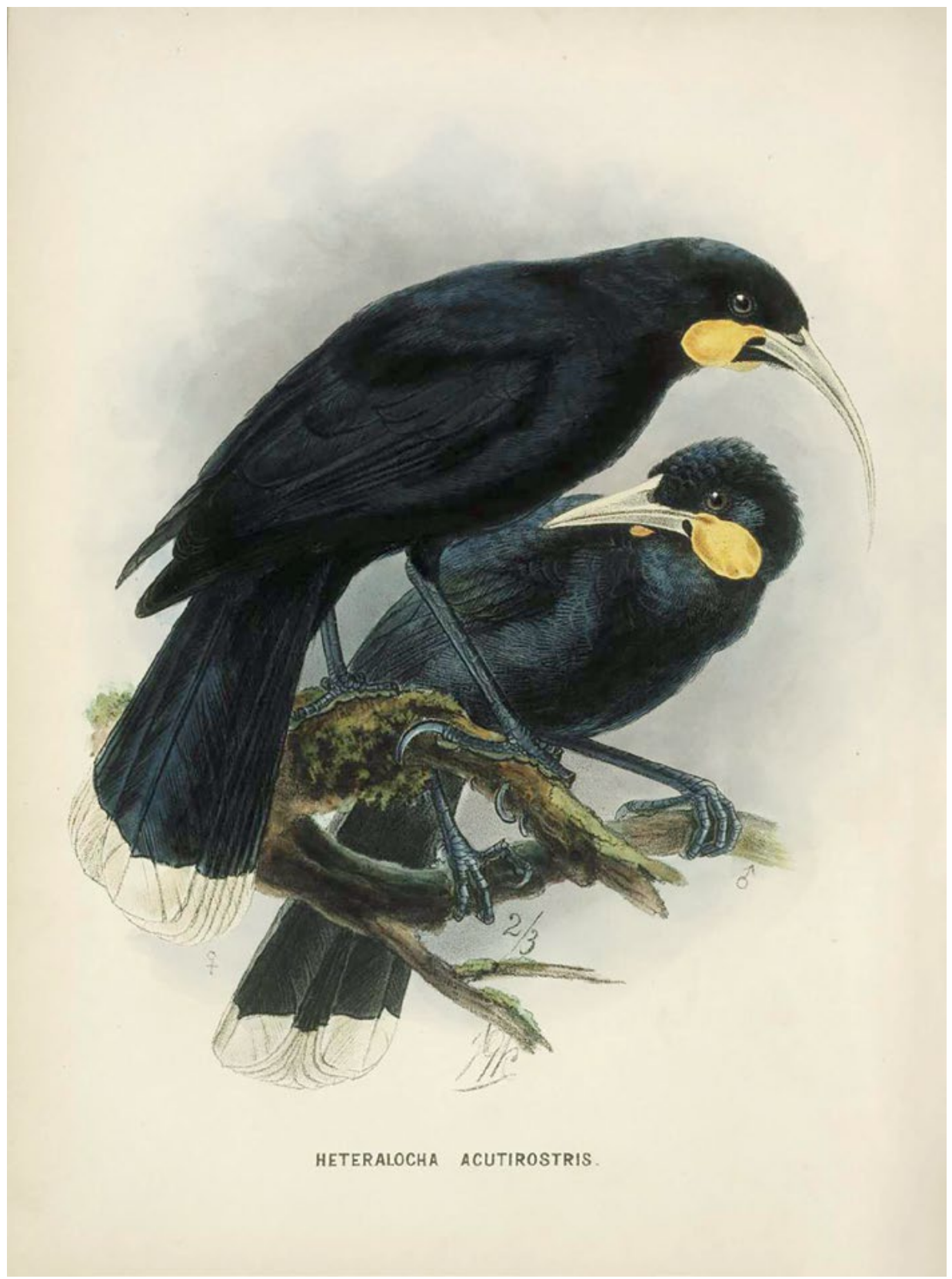

Figure 1: J. G. Keulemans, female (left) and male (right) huia.

Source: Walter Buller, A history of the birds of New Zealand, 1st ed. (London: John Van Voorst, 1873). Bib\#180551. Macmillan Brown Library, University of Canterbury. 
Even the preserved specimens of birds that Keulemans, Buller, and others produced for study and collections were subject to representational conventions. ${ }^{73}$ Aside from the grim distortions that poorly executed taxidermy can engender, specimens could be posed or arranged in ways that imply-intentionally or otherwisecertain movements, behaviours, or modes of sociality. Rachel Poliquin describes how ' $[\mathrm{t}]$ axidermy is one medium for imposing the possibility of meaning' ${ }^{74}$ which aligns it with the other representational technologies that, individually or as a link within a sequence, refract the impressions that posterity has inherited of the extinct birds. Furthermore, even the birds' collected skins-which did not always go on to be stuffed and posed, thus often sidestepping the arguable deceit of purporting to be lifelike-could be manipulated, as an anecdote in Galbreath's biography of Buller suggests. Buller was excited to have obtained live what he thought was a 'beautiful Mountain parroquet green and crimson-new to science'. ${ }^{75}$ However, when the bird started to moult her red feathers, 'revealing the plumage of a common Yellowcrowned Parakeet[,] Buller quickly turned it into a cabinet specimen while it still had some rarity value'. ${ }^{76}$ The bird was thus rather deceptively frozen in a particular stage of her appearance. The dynamic nature of the birds that became extinct, both in terms of their movements and the cycles of their lives-seasonally, and as they matured from chicks to adults - was served inadequately by the means of visual representation available in this period. ${ }^{77}$

For the second edition of 1888, Buller again emphasised the images-all of which were newly made — and championed Keulemans's considerable skill. He claimed the book would contain 'beautiful coloured drawings by Mr Keulemans, the birds being represented as they appear in life, with accessories drawn from the native flora of the country. These will be highly finished pictures in the best style of modern art' (italics mine). ${ }^{78}$ As well as Keulemans's unfamiliarity with Aotearoa somewhat challenging this assertion, Buller's words further suggest potentially compromising dissonances between scientific, aesthetic, and commercial considerations, the last of which appear to have necessitated the books' production as prestigious objects of significant

\footnotetext{
73 This is especially the case when these specimens are framed in the context of museum displays.

74 Rachel Poliquin, The breathless zoo: Taxidermy and the cultures of longing (University Park, PA: Pennsylvania State University Press, 2012), 9.

75 Walter Buller, quoted in Galbreath, Walter Buller, 83.

76 Galbreath, Walter Buller, 83.

77 Verbal descriptions of the birds' movements, behaviours, sounds and so on do of course exist, however, including Māori oral histories, and Buller's many observations of birds both in the wild and in captivity. See also, for example, Murdoch Riley, Mãori bird lore: An introduction (Paraparaumu: Viking Sevenseas, 2001). Furthermore, the vocalisations of some species were recorded before they became extinct.

78 Walter Buller, 'Notice of the new edition', reproduced in A history of the birds of New Zealand (London: The author, 1888), ix.
} 
cultural capital. Indeed, for this edition Buller apparently had requested that Keulemans make the background vegetation in the images more substantial than in the first. As Keulemans had not visited any of these environments, while he might have been familiar with some of the types of plant from botanical gardens, representing their interactions - like those of his avian subjects which were perching on these plants—-would have required significant guesswork.

In the 1888 volume, this time chromolithography was used to reproduce the illustrations, and the images were limited to what could be achieved working with six colours. ${ }^{79}$ The huia in this book appear more three-dimensional than those in copies of the first edition, and notably their colour is substantially differentas Galbreath notes, 'the special greasy inks required for the [chromo]lithographic process led to a predominance of olive tones' (Figure 2). ${ }^{80}$ While colouration is of course critical if visual representations of natural specimens are not to be misleading, as Jennifer Roberts notes in her excellent book Transporting visions: The movement of images in early America, 'color was one of the least portable qualities of ornithological specimens ${ }^{81}$ - even before the further distortions of printing processes. This rapid deterioration suggests why skins and taxidermy have limited capacity to indicate subtleties in the colouration of the living birds' plumage, both for observers today as well as for Keulemans, whom the specimens reached usually after several months in transit over land and sea. Indeed, Buller's approach to his books' images stands in marked contrast to Audubon's for Birds of America from earlier in the nineteenth century (1827-38), which Roberts incisively describes. Audubon's approach involved 'working in the field with freshly killed birds that he had shot himself', ${ }^{82}$ and adhered to a strict and richly suggestive 1:1 scale throughout. Something particularly fascinating about the case of the huia is that there appear to be no known photographs of the living birds, despite the species' twentieth-century extinction date. ${ }^{83}$ This seems even stranger when one considers

79 While the exigencies of chromolithography would have imposed other constraints on the images too, the method did mean that Keulemans retained more uniform control over the colouration of the finished illustrations. Indeed, Keulemans himself prepared some of these lithographic plates, and closely supervised the remainder, onto which his images were transferred by others. Galbreath describes the technical demands of this painstaking process, concluding that its strictures meant that 'chromolithographs lacked the spontaneity and freedom of line of the single lithograph' (160). Indeed, it is interesting to note that for the full-page, coloured illustrations in the third and final Birds book of 1905, this original method, in which single lithographic prints were hand-coloured, was returned to. Poignantly, a full-page illustration of the huia is absent from this edition. See Buller, Supplement to the 'Birds of New Zealand' (1905).

80 Galbreath, Walter Buller, 160.

81 Jennifer Roberts, Transporting visions: The movement of images in early America (Berkeley and Los Angeles, CA: University of California Press, 2014), 109. Indeed, W. J. Phillipps made observations to a similar effect about huia specifically, having noticed that most specimens in New Zealand museums 'exhibit considerable fading, more evident in older birds than in the young'- see Phillipps, The book of the huia, 33. Buller also appears to have been aware of how quickly colour degraded in specimens, and devised a technique for attempting to halt this process in the beaks of huia specimens.

82 Roberts, Transporting visions, 71.

83 Errol Fuller, Lost animals: Extinction and the photographic record (London: Bloomsbury, 2013), 13. 
that various huia were kept in captivity—sometimes expressly for observation—long after photographic technologies were widely used. ${ }^{84}$ As striking as this is, however, the existence of photographs of huia would do little to change my arguments here. Photographers, like other artists, consciously or otherwise interpret as they represent, and as with drawings, photographs distort-especially when heavily reliant on established pictorial conventions, as many photographs were in the nineteenth century. Furthermore, in terms of their success in reproducing detail, photographs in this period were often grainy, blurred, badly lit or worse, so were thought by some to be inferior to 'scientific' drawings. With the technology available at the time, it would have been difficult to capture clear photographs of New Zealand birds in their native habitats (often dense bush), and while photographs could be hand-coloured, colour photography prior to the twentieth century was largely experimental only. ${ }^{85}$

84 Fuller concurs: 'It is surprising to find that other more recently extinct creatures were not caught on camera. New Zealand's Huia (Heteralocha acutirostris), for instance, didn't become extinct until the early years of the twentieth century, and several pairs were kept in captivity'. Fuller, Lost animals, 13. However, given the close control of these birds' environments, and the likely impacts of this upon their behaviour, photographs of captive huia would have had different hermeneutic implications to photographs taken of huia in the wild. Photographs of other birds did, however, appear in the third edition of Buller's Birds, but interestingly in a supporting capacity rather than as the full-page principal illustrations - see Buller, Supplement to the 'Birds of New Zealand' (1905).

85 In other research I have examined the somewhat anachronistic approach to scientific representation employed in at least the first two editions of Buller's Birds in relation to Daston and Galison's work on the development of the notion of objectivity. The images in Buller's books appear to conform to a highly selective and 'generalising' paradigm of natural history illustration, significantly predating the period in which they were made, which Daston and Galison would describe as 'truth to nature'. This is despite the fact that these bird images were made during a period in which mechanical reproduction was, as Daston and Galison show, transforming scientific representation and reconfiguring notions of the 'scientific self' towards the idea of the self-abnegating and non-selective observer. My research discussed some potential epistemological implications of Buller's chosen representational convention, and examined the possibility that his awareness (and indeed ready acceptance) of the imminent extinction of many of these bird species might have contributed to his decision to illustrate the birds in this non-specific, archetypal, and memorialising way. Furthermore, Buller's gravely deleterious interactions with such birds as the huia rendered any posture as a non-interfering observer untenable. While the successes of manual objectivity-which captured for the first time images of such as bacteria, snowflakes, lightning, and other phenomena-revealed previously unseeable things to supposedly ascetic, patient scientists, birds on the brink of extinction arguably had already been drawn into too dynamic a struggle with their observers. Indeed, de-extinction attempts might be seen as constituting an extension of this, except with the opposite goal in mind. Parallels might also be made between the process of 'truth to nature' image-making - which involved the selection or rejection of features to be included in the representation-and both processes involved in some de-extinction methods (to reconstruct selected traits, including through reconstructing parts of ancient DNA), and the ecological 'curating', consciously or otherwise, of the Anthropocenic environment. For discussions of historical shifts in scientific illustration and the development of the notion of 'objectivity', see Daston and Galison, Objectivity. 


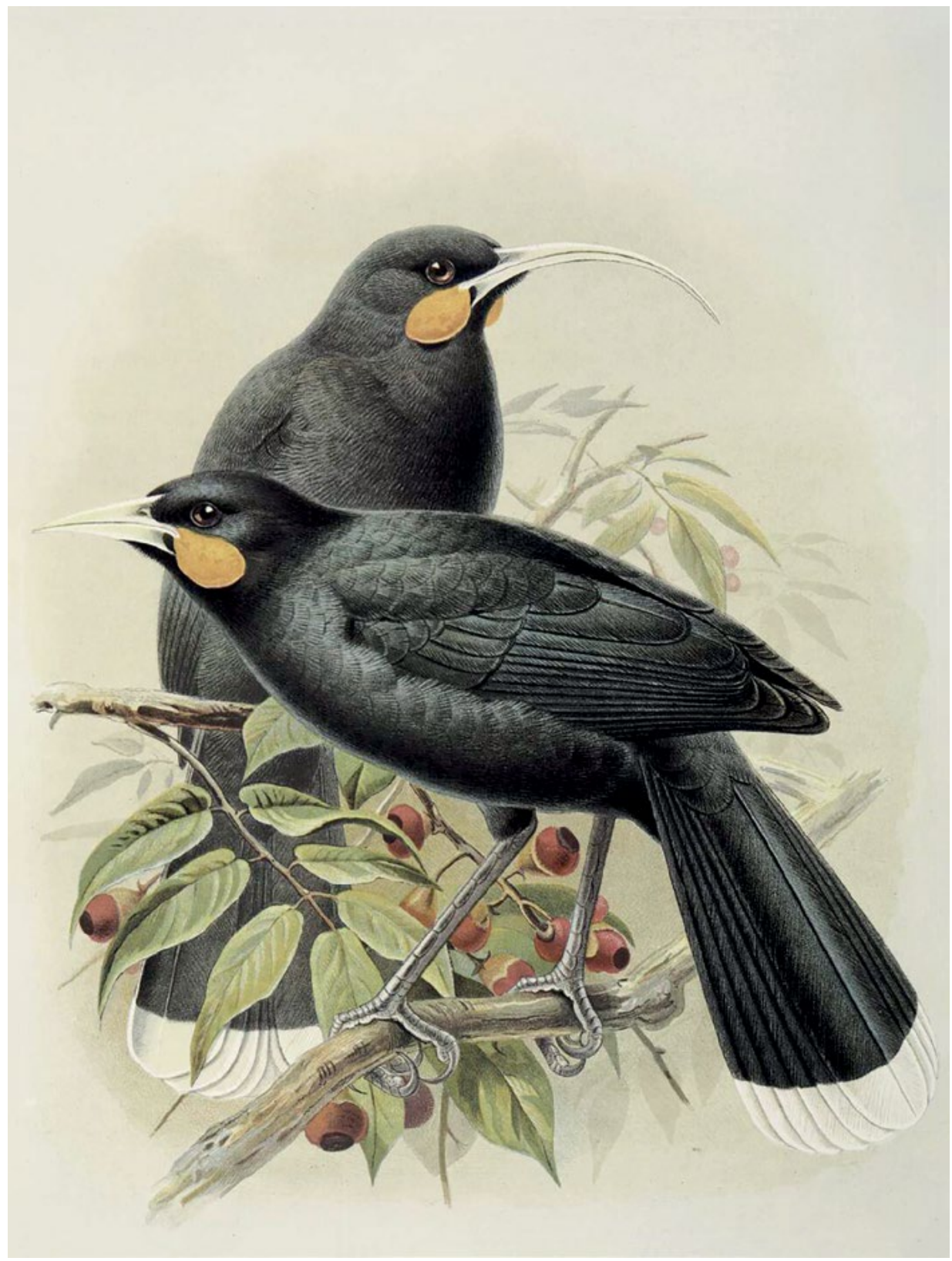

Figure 2: J. G. Keulemans, female (back) and male (front) huia.

Source: Walter Buller, A history of the birds of New Zealand, 2nd ed. (London: The author, 1888). Bib\#104983. Macmillan Brown Library, University of Canterbury. 
In any event, differences between sensory perception in humans, birds, and other non-human animals surely render human assessments of such things as visual likeness somewhat obsolete. If the ocular capacities of a candidate species for de-extinction differed from those of humans, then it is far from certain that the visual characteristics that helped individuals within that species to interact would have been adequately captured by images that humans made of them-including photographs, and moving images on film. ${ }^{86}$ As Francisco J. Varela, Adrian G. Palacios, and Timothy H. Goldsmith note, for example, 'The role of color vision in an animal's perception, behaviour, and ecological setting, and its underlying retina and neuronal mechanisms vary enormously in different groups of animals. Amidst this diversity, birds have arguably the most elaborate and interesting color vision' ${ }^{87}$ Further, it is perhaps less certain still that any such characteristicsevident to particular species but not taken into account in anthropocentric and biased practices of image-making - would translate back so as to be expressed in resurrected members of a species made using any de-extinction method informed by visual representations. This indicates significant potential for semiotic disruption within species recuperated following extinction, as well as the need for discourses around visual culture to be aware of potential implications of a more multispecies phenomenology.

\section{Conclusion}

In highlighting the museological and art-historical debates that might enrich discourses around de-extinction, I seek to be mindful of how, as Clark argues, much environmental criticism might be vulnerable to delusions that the sphere of cultural representations has more centrality and power than in fact it has' ${ }^{8} 8$ Furthermore, my aim is not to imply that the analogy between museums and the Anthropocene is anywhere near a perfect fit. Living things must in so many ways be understood differently to material culture, and indeed a criticism of de-extinction is its problematic objectification and commoditisation of living things. ${ }^{89}$

\footnotetext{
86 Unfortunately, biases have routinely been incorporated into the way film and digital technology — both for still and moving images — are colour-balanced. Lorna Roth, Syreeta McFadden, Rosie Cima, Adam Broomberg and Oliver Chanarin, among others, have critiqued this in relation to images of people, exploring how racism has been encoded within photographic representation. See, for example, Lorna Roth, 'Looking at Shirley, the ultimate norm: Colour balance, image technologies, and cognitive equity', Canadian Journal of Communication 34 (2009): 111-36, doi.org/10.22230/cjc.2009v34n1a2196.

87 Francisco J. Varela, Adrian G. Palacios, and Timothy H. Goldsmith, 'Color vision of birds', in Vision, brain, and behavior in birds, ed. H. Philip Zeigler and Hans-Joachim Bischof (Cambridge, MA, and London: MIT Press, 1993), 77.

88 Clark, Ecocriticism on the edge, 21.

89 See Martinelli, Oksanen, and Siipi, 'De-extinction'.
} 
The cinematically heralded notion of de-extinction must also not obscure the more modest interventions nested within the term, which might involve such approaches as making small genetic modifications within populations of still-extant species, or the use of assisted reproductive technologies ('ARTs') ${ }^{90}$ for species termed 'living dead'. It is therefore important not to make a so-called 'straw man' out of de-extinction by focusing only on its most outlandish proposals and manifestations. Indeed, Shapiro insists that, for her at least, '[t] he task ahead is not to make perfect replicas of species that were once alive' ${ }^{91}$ While this might seem to neutralise my argument's concerns around the accuracy of the visual record, it implicitly assumes that what constitutes a 'perfect replica' is actually knowable - as well as disregarding potential needs of the species themselves (possibly even needs fundamental to how members of a species communicate, or interact with other species). Further, these more minimal interventions into species diversity might call into question some scientists' utilisation of the optics of 'de-extinction' for what arguably could also be presented as more modest proposals. ${ }^{92}$

It is perhaps worth noting that Buller's images of the huia, surrounded by little foliage and lots of space, are close to what Roberts has referred to as the 'bird-ona-stick' mode of natural history illustration. ${ }^{93}$ This format perhaps has the effect of belying the complex ecological entanglements of species-entanglements that humans too are part of, and which arguably obscure our ability to conceive of the Anthropocene at the (supposed) distance to which we are accustomed in practices of 'scientific' looking. As Ed Ayres has observed, '[w]e are being confronted by something so completely outside our collective experience that we don't really see it, even when the evidence is overwhelming'. ${ }^{94}$ This reinforces the notion that the Anthropocene is facilitated in part by a crisis of representation, which-in its operations on both macro and micro levels_-might be impossible fully to overcome. While this article does not seek to posit uncertainties around the visual record as in themselves necessarily an argument against de-extinction practices, it does hope to suggest the importance of plurality within the sources considered when trying to get to know extinct species. For the huia and a great number of other lost species, their representation and understanding in indigenous knowledge systems and practices are key parts of this.

\footnotetext{
90 See Heatherington, 'From ecocide to genetic rescue', 41.

91 Shapiro continues, 'First, it is technically not possible to do so and is unlikely ever to become technically possible to do so. Second, there is no compelling reason to make perfect replicas of extinct species' (205). However, many would contest these assertions, and it is also possible that certain strands of enthusiasm for de-extinction would be dampened if it were more widely understood that 'identical' versions of lost species are not necessarily the goal. 92 However, if, as Žižek cautions, 'one should imagine a possible global disaster ... [as] no big bang, just a smallscale interruption with devastating global consequences', by this logic 'smaller' interventions should not necessarily be conceptualised as less controversial. Žižek, Living in the end times, 350.

93 Roberts, Transporting visions, 97.

94 Ed Ayres, quoted in Žižek, Living in the end times, 327.
} 
Similarly floating in space-like the 'bird on a stick', ostensibly devoid of systemic interactions - is the Earth in pictures taken during the Apollo 8 mission, among the first images of their kind. In a fascinating analysis, Clark describes one of these as a quintessential symbol of the Anthropocene with multiple available readings. It can be seen, he points out, variously 'as an icon of life's almost unbearable fragility; as the achievement through technology of the age-old dream of a god's-eye view; an instance of the contingent privilege of vision in the human sense of what something "really" is ... a terrifying view of its target from a weapons platform'. ${ }^{95}$ This last part links uncannily with the images of huia in Buller's books, since his observation of these birds in the wild was usually followed by their being shot. ${ }^{96}$ Their attitudes as recorded in his books might therefore be read as indexical of those of birds just before their deaths. Clark's notion of the 'weapons platform' suggests advanced technology turning in on itself, and warns of the perils of the kind of anthropocentric hubris that eradicated the huia and many other extinct animals, and_-some might argue_-now attempts to bring these species back. ${ }^{97}$

95 Clark, Ecocriticism on the edge, 30.

96 For one perspective on relationships between hunting and how killed animals have been framed, see Garry Marvin, 'Enlivened through memory: hunters and Hunting trophies', in The afterlives of animals: A museum menagerie, ed. Samuel J. M. M. Alberti (Charlottesville, VA, and London: University of Virginia Press, 2011), 202-17.

97 This article is based on papers I presented at the Australasian Victorian Studies Association conference in Auckland in February 2015, at the College Art Association conference in Washington, DC, in February 2016, and in Christchurch for the New Zealand Centre for Human-Animal Studies in April 2016. 
This text is taken from International Review of Environmental History, Volume 3, Issue 1, 2017, edited by James Beattie, published 2017 by ANU Press, The Australian National University, Canberra, Australia. 